\title{
Meningkatkan Keterampilan Berpikir Kritis Peserta Didik Melalui Pembelajaran IPA Berbasis Potensi Lokal Jepara
}

\author{
Aries Anisa \\ SMP Negeri 1 Kedung Jepara. Sowan Lor, Kecamatan Kedung, Kabupaten Jepara 59463, Indonesia \\ Email: aries.anisa@gmail.com
}

Received: 20 April 2016; Revised: 8 May 2017; Accepted: 8 June 2017

\begin{abstract}
Abstrak
Penelitian ini bertujuan untuk menganalisis efektivitas pembelajaran IPA berbasis potensi lokal Jepara untuk meningkatkan keterampilan berpikir kritis peserta didik SMPN 1 Bangsri Jepara. Metode penelitian ini adalah kuasi ekspreimen dengan cluster random sampling dan pretest-posttest control group design. Instrumen yang digunakan adalah RPP dan LKPD berbasis potensi lokal Jepara serta soal keterampilan berpikir kritis yang telah valid melalui validasi ahli, praktisi dan teman sejawat.Aktivitas pembelajaran IPA pada penelitian ini memungkinkan peserta didik memperoleh pengalaman secara langsung melalui interaksi dengan pelaku wirausahapembuatan gerabah dan mebel Jepara sebagai bagian potensi lokal Jepara yang berkaitan dengan materi pembelajaran IPA.Hal ini diharapkan mampu meningkatkan keterampilan berpikir kritis peserta didik dalam menyambut era globalisasi saat ini.Hasil penelitian menunjukkan pembelajaran IPA berbasis potensi lokal Jepara efektif untuk meningkatkan keterampilan berpikir kritis peserta didik SMPN 1 Bangsri Jepara.Efektivitas pembelajaran ini ditunjukkan berdasarkan hasil uji t dengan nilai sig. 0,000.
\end{abstract}

Kata Kunci: pembelajaran IPA, potensi lokal, keterampilan berpikir kritis

\section{Improving Students'Critical Thinking Skill Through Science Teaching Based on Jepara's Local Potential}

\begin{abstract}
This research aims to analyzing the effectiveness of science teaching based on Jepara's local potential to improve students' critical thinking skill of SMPN 1 Bangsri Jepara. The mothods of research is quasi-experiment with the cluster random sampling and pretest-posttest control group design. Instruments of the research are lesson plan, student worksheet, and critical thinking skill test which have been valid through the expert, teacher, and peers validation.Thescience learning activity of this research makes studentsgain the experience directly through interaction with entrepreneurs of making pottery and furniture as part of Jepara's local potentialthat related to science subject.It is expected to improve critical thinking skill of students to commemorateglobalization. The result of the research is science teaching based on Jepara's local potential effective to improvestudents' critical thinking skill of SMPN 1 Bangsri Jepara. The effectiveness of science teaching obtained from t test at sig. 0,000.
\end{abstract}

Keywords: science teaching, local potential, critical thinking skill

How to Cite: Anisa, A. (2017). Meningkatkan keterampilan berpikir kritis peserta didik melalui pembelajaran IPA berbasis potensi lokal Jepara. Jurnal Inovasi Pendidikan IPA, 3(1), 1-11. doi:http://dx.doi.org/10.21831/jipi.v3i1.8607

Permalink/DOI: http://dx.doi.org/10.21831/jipi.v3i1.8607 


\section{PENDAHULUAN}

Indonesia merupakan negara yang kaya akan ragam potensi, budaya dan sumber daya alam di tiap daerahnya. Parmin, Sajidan, Ashadi, \& Sutikno menyatakan bahwa "Indonesian society has a variety of traditions, habits, and values of life that has been used for generations as a guide, which in the past has proven capable of maintaining the environmental balance" (Parmin, Sajidan, Ashadi, \& Sutikno, 2015, p. 121). Masyarakat Indonesia memiliki berbagai tradisi, kebiasaan, dan nilai-nilai kehidupan yang telah digunakan selama beberapa generasi sebagai panduan, yang di masa lalu telah terbukti mampu menjaga keseimbangan lingkungan. Potensi daerah yang ada di Indonesia sungguh melimpah, termasuk potensi lokal yang berhubungan dengan dunia wirausaha (home industry). Potensi lokal adalah potensi yang dimiliki suatu daerah yang meliputi potensi sumber daya alam, potensi sumber daya manusia, geografis, budaya, dan historis (Mumpuni). Sejalan dengan itu, keunggulan lokal (potensi lokal) disebut juga sebagai segala sesuatu yang menjadi ciri khas kedaerahan yang mencakup hasil bumi, kreasi seni, tradisi, budaya, pelayanan, jasa, sumber daya alam, sumber daya manusia, atau lainya yang menjadi keunggulan suatu daerah (Kanzunnudin \& Oktavianti, 2014, p. 6). Potensi lokal merupakan kegiatan masyarakat atau industri yang ada di suatu lokal atau daerah yang dapat mendukung kegiatan pembelajaran.

Setiap daerah memiliki letak lokasi yang menyebabkan perbedaan potensi lokal masingmasing. Jepara adalah salah satu kabupaten di Provinsi Jawa Tengah yang memiliki banyak potensi lokal di beberapa kabupaten, di antaranya industri pembuatan Gerabah di Mayong, industri Mebel di Mlonggo, industri Monel di Kalinyamatan, industri tenun troso di Pecangaan, dan industri pembuatan batu bata di Welahan.

Keberadaan Kabupaten Jepara di Provinsi Jawa Tengah yang memiliki banyak potensi lokal tersebut dapat dimanfaatkan dan diintegrasikan dalam proses pembelajaran sains di segala jenjang pendidikan, termasuk materi IPA dalam kurikulum 2013 kelas VIII SMP. Strategi pengintegrsian potensi lokal dalam pembelajaran dapat dilakukan dengan memodifikasi indikator pembelajaran (Santoso, 2010). Potensi lokal yang ada, dapat terkait dengan mata pencaharian masyarakat sekitar. Adapun mata pencaharian penduduk Jepara mayoritas di bidang pertanian, industri pengolahan, jasa, dan perdagangan yang tersebar di berbagai kecamatan di Kabupaten Jepara. Industri pengolahan yang dimaksudkan diantaranya dalam bentuk mebel (pengolahan kayu), konveksi, tenun, dan berbagai macam industri kerajinan (Sunarto, Marfai, \& Setiawan, 2014, p. 154).

Potensi lokal yang ada di Kabupaten Jepara di antaranya, sentra konveksi di Desa Sendang Kecamatan Kalinyamatan, kerajinan tenun troso di Desa Troso yang berada di Kecamatan Pecangaan, kerajinan monel di Desa Kriyan Kecamatan Kalinyamatan, dan Kecamatan Kembang sebagai daerah sentra tanaman karet. Kecamatan Mlonggo merupakan salah satu kecamatan yang menjadi kawasan industri mebel di Kabupaten Jepara selain Kecamatan Tahunan, baik skala kecil maupun besar. Selain itu, terdapat sentra kerajinan berbahan dasar tanah liat yang berada di Kecamatan Mayong yang merupakan kawasan pembuatan gerabah dan di Kecamatan Welahan yang merupakan sentra pembuatan batu bata, namun dalam kajian ini akan fokus pada pembuatan gerabah di Kecamatan Mayong dan pembuatan mebel di Kecamatan Mlonggo.

Potensi lokal pembuatan gerabah di Kecamatan mayong berasal dari sumber daya alam berupa tanah liat. Tanah yang digunakan sebagai bahan dasar pembuatan kreasi kerajinan gerabah diproses melalui beberapa tahap (Gambar 1 dan Gambar 2). Tahap pada pembuatan gerabah setidaknya terdiri atas pengambilan tanah, persiapan tanah sehingga tanah menjadi liat dan halus, pembentukan gerabah menggunakan teknik putar tradisional, pengeringan menggunakan sushu ruang, pembakaran dengan pemanasan secara bertahap hingga mencapai suhu $1200^{\circ} \mathrm{C}$, serta penyempurnaan (finishing) saat pengentasan dalam kondisi masih membara dari tungku sambil dilakukan pewarnaan menggunakan bekatul yang dibakar pada dinding luar gerabah.

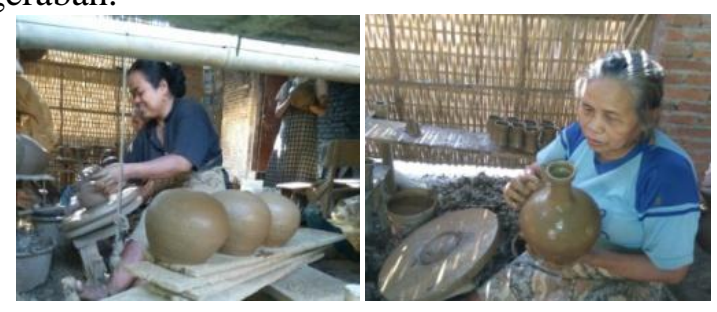

Gambar 1. Proses Pembuatan Gerabah 


\section{Jurnal Inovasi Pendidikan IPA, 3 (1), 2017 - 3}

Aries Anisa

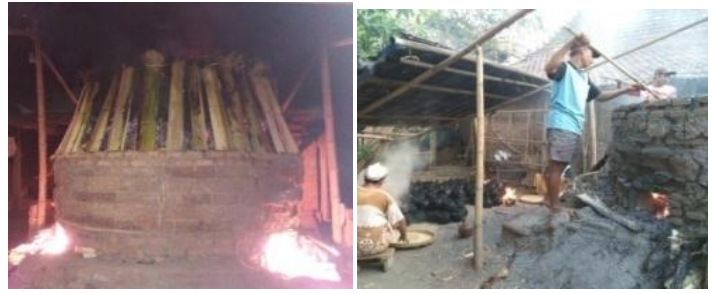

Gambar 2. Proses Pembuatan Gerabah

Potensi lokal mebel Jepara merupakan industri yang memerlukan bahan dasar kayu untuk diproses menjadi berbagai macam produk mebelair dalam rumah tangga, seperti meja, kursi, lemari, dipan, dan beberapa pernak-pernik souvenir dari kayu. Jenis kayu yang digunakan menyesuaikan tujuan dan kebutuhan, serta jenis produk yang akan dihasilkan. Kayu dari pohon yang berbeda mempunyai sifat yang berbeda pula, sehingga pemanfaatannya juga berbeda. Sifat kayu yang perlu diperhatikan sebelum proses pembentukan menjadi produk mebelair adalah berat jenis, keawetan, kekerasan, warna, tekstur, nilai dekoratif, kesan raba, bau, dan rasa.

Adapun beberapa tahap pengolahan kayu pada industri mebel Jepara seperti ditunjukkan pada Gambar 3 ada tujuh tahap, yaitu: tahap persiapan, tahap pengeringan, tahap pembentukan, tahap penghalusan, tahap pengeleman, tahap penghalusan kedua, dan tahap finishing.

Tahap persiapan merupakan tahap pemilihan bahan kayu yang bagus untuk bahan dasar pembuatan mebel. Tahap pengeringan adalah proses kayu dikeringkan dengan cara penjemuran menggunakan sinar matahari. Tahap pembentukan bagian mebel yang akan dibuat: kayu dipotong atau digergaji membentuk bagianbagian mebel yang akan dibuat.

Tahap penghalusan/pengamplasan pertama dilakukan pada masing-masing bagian mebel dihaluskan dengan cara diamplas. Tahap pengeleman adalah proses masing-masing bagian mebel dirangkai hingga menjadi produk mebel mentah. Tahap pengalusan kedua dilakukan setelah mebel mentah jadi, kemudian dihaluskan lagi hingga benar-benar halus dan siap dicat atau diwarnai hingga menjadi mebel yang matang. Tahap terakhir (tahap finishing)yaitu mebel mentah yang sudah dihaluskan, dicat atau diplitur hingga menjadi produk mebel akhir.

Pemanfaatan potensi daerah (potensi lokal) dalam pembelajaran sangat diperlukan, salah satunya dalam pengembangan perangkat pembelajaran. Salah satu bentuk perangkat pembelajaran yang dimaksud adalah lembar kerja peserta didik (LKPD) ang dapat memberikan panduan dalam pembelajaran dan menjadikan peserta didik memahami materi dengan aktivitas yang memberikan pengalaman secara langsung dengan sumber belajar terkait.Peserta didik menjadi lebih kreatif dan leluasa dalam menggali dan menganalisis segala informasi terkait materi pembelajaran secara mendalam terhadap sumber belajar terkait, sehingga dapat meningkatkan keterampilan berpikir kritis peserta didik. Sumber belajar dapat diperoleh dengan memanfaatkan potensi lokal sekitar sekolah. Hal ini sejalan dengan Peraturan Menteri Pendidikan dan Kebudayaan RI nomor 103 Tahun 2014 tentang Pembelajaran pada Pendidikan Dasar dan Pendidikan Menengah, bahwa "Pembelajaran adalah proses interaksi antarpeserta didik dan antara peserta didik dengan pendidik dan sumber belajar pada suatu lingkungan belajar" (Mendikbud, 2014).

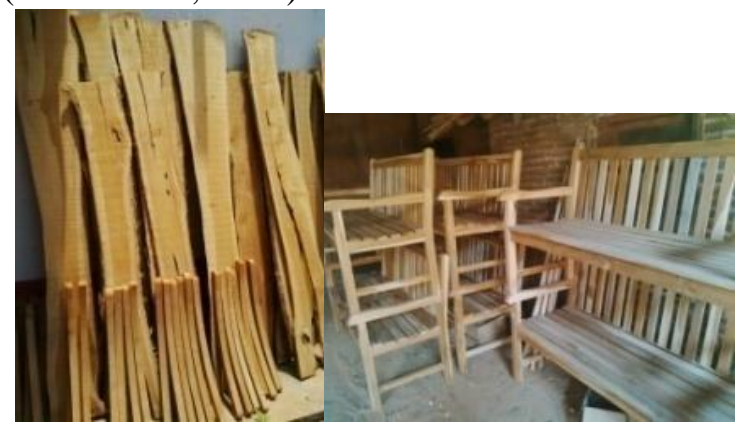

Gambar 2. Tahap Pembuatan Mebel Jepara

Terdapat banyak materi pembelajaran yang dapat memanfaatkan potensi lokal di lingkungan sekitar sekolah, khususnya materi pembelajaran IPA. IPA (Sains) hendaknya dipandang sebagai cara berpikir untuk tujuan memahami alam, sebagai sebuah cara investigasi untuk menyatakan tentang fenomena, dan sebagai sebuah batang tubuh ilmu pengetahuan yang dihasilkan dari inkuiri (Collete \& Chiappetta, 1994, p. 30). Proses pembelajaran ilmu pengetahuan alam (IPA) sebagai bagian dari sistem pendidikan menggunakan pendekatan ilmiah dan kontekstual untuk membuat pengetahuan yang dipelajari menjadi lebih bermakna. Pembelajaran yang bermakna ini akan terasa saat persiapan pembelajaran dilakukan dengan memperhatikan kebutuhan dan keterlibatan peserta didik secara maksimal.

Pembelajaran IPA diharapkan dapat menumbuhkan karakter peserta didik untuk dapat lebih menghargai budaya maupun sumber daya yang ada di sekitarnya (Khusniati, 2014, p. 67). Dalam pembelajaran IPA diutamakan proses penekanan pemberian pengalaman langsung 
untuk mengembangkan kemampuan agar peserta didik mampu menjelajahi dan memahami alam sekitar (potensi lokal) secara ilmiah dengan mencari tahu dan berbuat ataupun berinteraksi secara langsung. Hal ini membantu peserta didik untuk memperoleh pengalaman yang lebih mendalam tentang alam sekitar berupa fakta, konsep, prinsip, hukum alam, model, dan teori yang membentuk pengetahuan. Pengalaman yang mendalam ini akan diperoleh peserta didik dengan terlibat dalam pembelajaran IPA berbasis lingkungan (potensi lokal) yang terkait.

Pengalaman langsung di lingkungan sekitar dalam proses pembelajaran merupakan cara efektif untuk melatih keterampilan berpikir kritis peserta didik sebagai tuntutan perkembangan zaman. Perkembangan zaman yang pesat seiring dengan pesatnya perkembangan ilmu pengetahuan, teknologi dan informasi dalam kehidupan. Perkembangan ilmu pengetahuan,teknologi, dan informasi di abad XXI saat ini telah membawa perubahan pada segala aspek kehidupan, termasuk dalam dunia industri dan perekonomian yang membutuhkan kesiapan sumber daya terkait.Sebagai salah satu negara anggota ASEAN (Association of South East Asian Nations), Indonesia sudah selayaknya menyiapkan segala sumber daya untuk menyambut MEA (Masyarakat Ekonomi ASEAN). Sumber Daya Manusia (SDM) berkualitas dan berkarakter sebagai calon penerus bangsa merupakan salah satu ciri seorang yang memiliki keterampilan berpikir kritis yang diharapkan mampu menyongsong era MEA pada abad XXI. Upaya untuk menyiapkan generasi penerus bangsa yang berkualitas dan berkarakter sedang dilaksanakan oleh bangsa Indonesia untuk meningkatkan kualitas SDM Indonesia. Upaya ini dapat ditempuh melalui pendidikan dalam sebuah proses pembelajaran IPA untuk meningkatkan keterampilan berpikir kritis dalam menjawab tuntutan perkembanganilmu pengetahuan dan teknologi di abad XXI. Pendidikan menjadi salah satu jalur untuk dapat menjawab tantangan abad XXI berupa pemenuhan SDM yang berkualitas (Syarifah \& Sumardi, 2015). Hal ini sesuai dengan pernyataan Presiden Republik Indonesia dalam UU No. 20 Tahun 2003, tentang Sistem Pendidikan Nasional, Bab II Pasal 3(Republik Indonesia, 2003) bahwa:

Pendidikan Nasional berfungsi mengembangkan kemampuan dan membentuk watak serta peradaban bangsa yang bermartabat dalam rangka mencerdaskan kehidupan bangsa, bertujuan mengembangkan potensi peserta didik agar menjadi manusia yang beriman dan bertaqwa kepada Tuhan Yang Maha Esa, berakhlak mulia, sehat berilmu, cakap, kreatif, mandiri dan menjadi warga negara yang demokratis serta bertanggung jawab.

Keterampilan berpikir kritis dapat dikembangkan pada peserta didik melalui proses pembelajaran di sekolah. Keterampilan berpikir kritis merupakan keterampilan yang tidak dapat berkembang seiring perkembangan fisik seseorang (Wahyuni). Terdapat beberapa prinsip dalam berpikir kritis yang harus dipelajari (Fahim, 2012, p. 156).

Keterampilan berpikir kritis merupakan bagian dari keterampilan berpikir tingkat tinggi (high order thinking skill) (Uswatun \& Rohaeti, 2015). Berpikir kritis didefinisikan sebagai sebuah proses berpikir yang reflektif dan beralasan untuk memutuskan apa yang harus diyakini atau dilakukan (Ennis, 1985; Hunter, 2009, p. 2). Rudd, Baker \& Tracy (Cavus \& Uzunboylu, 2009)mengungkapkan bahwa berpikir kritis merupakan sebuah pendekatan pemecahan masalah yang reasonable, purposif, dan introspektif.

Keterampilan berpikir kritis meliputi keterampilan analisis, sintesis, interpretasi, evaluasi, dan membuat asumsi yang membekali peserta didik pada abad XXI (Sendag \& Odabasi, 2009). Seorang pemikir kritis diharapkan bisa menjadi agen perubahan dan jawaban atas tantangan abad XXI yang mampu membawa perubahan ke arah masa depan yang lebih baik (Syarifah \& Sumardi, 2015, p. 238). Adapun karakteristik pemikir kritis secara umum meliputi keterampilan menggunakan bukti; menghubungkan dan mengorganisasi pikiran secara ringkas dan koheren; kemampuan membedakan antara argumen dan rasionalisasi yang valid dan tidak valid; memahami perbedaan antar argumen dan rasionalisasi;kemampuan melihat kemiripan dan analogi terhadap sesuatu yang tidak tampak secara langsung; belajar secara bebas; kemampuan menggunakan teknik penyelesaian masalah; kemampuan menyampaikan pendapat bebas secara lisan dari informasi yang tepat; koreksi diri; dan kewaspadaan atas keterbatasan pada pemahaman sesuatu (Williams, 2011, p. 64).

Ennis berpendapat terdapat lima aspek atau kategori keterampilan berpikir kritis, yaitu: memberikan penjelasan sederhana; membangun keterampilan dasar; menyimpulkan; memberi- 


\section{Jurnal Inovasi Pendidikan IPA, 3 (1), 2017 - 5}

Aries Anisa

kan penjelasan lebih lanjut; serta strategi dan taktik (Afrizon, Ratnawulan, \& Fauzi, 2012).

Berdasarkan uraian tersebut, pada penelitian ini digunakan lima aspek keterampilan berpikir kritis, yaitu: memberikan penjelasan sederhana, keterampilan menghubungkan, membandingkan dan membedakan, analisis dan evaluasi, serta membuat dan menyampaikan kesimpulan.

\section{METODE}

Penelitian ini merupakan penelitian kuasi eksperimen. Penelitian ini dilaksanakan di Kabupaten Jepara, tepatnya di SMPN 1 Bangsri pada tahun pelajaran 2015/2016 semester 1 .

Subjek penelitian ini adalah peserta didik kelas VIII SMPN 1 Bangsari Kabupaten Jepara pada tahun pelajaran 2015/2016 semester 1 . Sekolah ini merupakan salah satu sekolah yang sudah melaksanakan Kurikulum 2013 di Kabupaten Jepara.

Penelitian ini dilakukan dengan metode kuasi eksperimen. Adapun populasi dalam penelitian ini adalah seluruh peserta didik kelas VIII SMPN 1 Bangsri Kabupaten Jepara. Sampel ditentukan dengan caracluster random sampling dari 9 kelas yang ada, diperoleh kelas VIII C sebagai kelas eksperimen dan kelas VIII B sebagai kelas kontrol.

Pembelajaran dalam penelitian ini dilakukan dengan menggunakan perangkat pembelajaran berbasis potensi lokal Jepara berupa RPP, LKPD, dan instrumen penilaian hasil belajar berbasis potensi lokal Jepara pada KD 3.3. yaitu mendeskripsikan keterkaitan sifat bahan dan pemanfaatannya dalam kehidupan sehari-hari, serta pengaruh pemanfaatan bahan tertentu terhadap kesehatan manusia merupakan materi baru yang ada di kurikulum 2013 (Mendikbud, 2014).

Pada kelas eksperimen, guru melaksanakan pembelajaran menggunakan perangkat berbasis potensi lokal pembuatan gerabah dan mebel Jepara, sedangkan pada kelas kontrol guru melaksanakan pembelajaran menggunakan perangkat pembelajaran yang biasa digunakan.

Model rancangan dalam penelitian kuasi eksperimen ini adalah pretest-posttest control group design seperti ditunjukkan pada Gambar 4. Peserta didik pada kelas eksperimen maupun kelas kontrol diberikan pretest dan posttest sebelum dan sesudah perlakuan berupasoal keterampilan berpikir kritis.

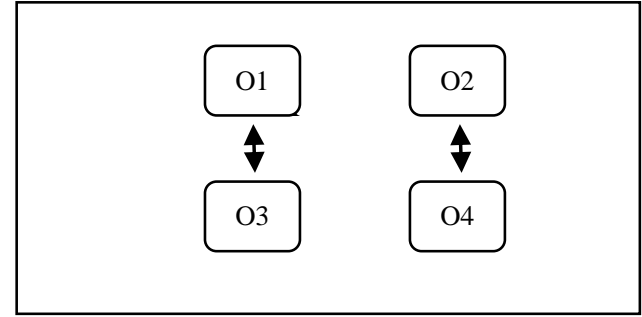

Gambar 4. Pretest-Postest Control Group Design (Sugiyono, 2014, p. 416)

Keterangan:

O1: pretest pada kelas eksperimen

$\mathrm{O} 2$ : posttest pada kelas eksperimen

O3: pretest pada kelas kontrol

O4: posttest pada kelas kontrol

Data pada penelitian ini diperoleh dengan menggunakan instrumen tes dan non-tes berupa lembar pedoman wawancara pada saat studi awal, soal keterampilan berpikir kritis untuk penilaian keterampilan berpikir kritis dan lembar observasi untuk pengamatan katerlaksanaan pembelajaran. Data hasil wawancara pada tahap studi awal, digunakan untuk mengetahui kebutuhan dan kondisi lapangan. Hasil data yang diperoleh dideskripsikan sebagai dasar penelitian ini dilakukan.

Keterampilan berpikir kritis diukur menggunakan soal tes keterampilan berpikir kritis yang terdiri atas 20 butir soal uraian telah dinyatakan valid melalui proses validasi ahli materi, ahli media, praktisi, dan teman sejawat. Soal ini digunakan untuk mengukur keterampilan berpikir kritis peserta didik. Pengamatan keterlaksanaan pembelajaran dilakukan dengan menggunakan lembar observasi keterlaksanaan RPP. Pengamatan dilakukan untuk mengukur persentase keterlaksanaan pembelajaran menggunakan perangkat pembelajaran berbasis potensi lokal Jepara. Pengamatan dilakukan oleh dua pengamat (observer) setiap proses pembelajaran berlangsung.

Data pretest dan posttest yang telah diperoleh saat penelitian, dihitung nilai gain standarnya terlebih dahulu sebelum dianalisis. Data gain diperoleh menggunakan teknik Gain Standar (Meltzer, 2002). Persamaan untuk teknik tersebut adalah:

Gain Standar $=\frac{\text { skor posttest }- \text { skor pretest }}{\text { skor maksimum }- \text { skor pretest }}$

Gain skor yang telah diperoleh dapat dikategorikan dalam kategori rendah, sedang, atau tinggi. Hake (1999) menjelaskan kategori gain standar sebagai berikut: $\langle\mathrm{g}\rangle \geq 0,7$ : gain tinggi 


\section{Jurnal Inovasi Pendidikan IPA, 3 (1), 2017 - 6}

Aries Anisa

$0,3 \leq\langle\mathrm{g}\rangle<0,7$ : gain sedang

$\langle$ g) $<0,3$ : gain rendah

Analisis yang dilakukan terdiri atas dua, yaitu analisis keterlaksanaan pembelajaran menggunakan perangkat pembelajaran berbasis potensi lokaldan analisis keefektifan pembelajaran berbasis potensi lokal Jepara untuk meningkatkan keterampilan berpikir kritis peserta didik.

Pada setiap pertemuan yang melaksanakan pembelajaran dengan menggunakan perangkat pembelajaran berbasis potensi lokal Jepara, dinilai menggunakan lembar angket keterlaksanaan pembelajarannya oleh dua orang pengamat, sehingga masing-masing diperoleh skor total. Keterlaksanaan pembelajaran menggunakan perangkat pembelajaran berbasis potensi lokal dinilai dari terlaksananya setiap butir dalam lembar pengamatan. Jumlah butir yang terlaksana dibagi dengan total butir sehingga diperoleh nilai keterlaksanaan dalam bentuk persentase. Adapun untuk menentukan persentase keterlaksanaan RPP tiap pengamat menggunakan persamaan berikut. $\%$ Keterlaksanaan $=\frac{\text { Banyaknya langkah pembelajran yang terlaksana }}{\text { banyaknya langkah pembelajaran }} \times 100 \%$

Keterlaksanaan perangkat berbasis potensi lokal dalam pembelajaran hasil pengamatan oleh dua pengamat dikatakan baik jika $\geq$ 0,75 atau $75 \%$ (Borich, Observation Skills for Effective Teaching, 1994, p. 385). Adapun untuk menentukan percent of agreement terhadap keterlaksanaan RPP menggunakan persamaan berikut.

Percentage of agreement $=100 \%\left[1-\frac{A-B}{A+B}\right]$

Keterangan:

$\mathrm{A}=$ Penilaian pengamat 1 (yang memberikan nilai tinggi)

$\mathrm{B}=$ Penilaian pengamat 2 (yang memberikan nilai rendah) (Borich, Observation Skills for Effective Teaching, 1994, p. 385).

Untuk mengetahui keefektifan pembelajaran berbasis potensi lokal pembuatan gerabah dan mebel Jepara dilakukan uji $\mathrm{t}$ pada data keterampilan berpikir kritis peserta didik.

Statistik uji $\mathrm{t}$ ini menuntut dua asumsi yang harus terpenuhi terlebih dahulu, yaitu data berdistribusi normal dan berasal dari populasi yang homogen univariat. Uji asumsi ini dilakukan pada skor gain standar keterampilan berpikir kritis peserta didik dengan bantuan program SPSS 22 pada taraf signifikansi $\alpha 5 \%$.
Uji normalitas dilakukan pada data skor gain standar yang telah dihitung dengan hipotesis sebagai berikut.

$\mathrm{H}_{0}$ : Data berasal dari populasi yang berdistribusi normal.

$\mathrm{H}_{a}$ : Data berasal dari populasi yang tidak berdistribusi normal.

Uji normalitas dilakukan pada masingmasing kelas eksperimen maupun kelas kontrol. Uji normalitas dilakukan menggunakan bantuan program SPSS 22 Saphiro Wilkspada taraf signifikansi $\alpha 5 \%$. Kriteria untuk melakukan uji normalitas pada tingkat signifikansi $\alpha 5 \%$ adalah data berasal dari populasi yang berdistribusi normal atau $\mathrm{H}_{0}$ diterima jika nilai signifikansi lebih besar dari nilai $\alpha($ sig. $>\alpha)$.

Uji asumsi selanjutnya adalah uji homogenitas.Uji homogenitas dilakukan untuk mengetahui apakah populasi kedua sampel homogen atau tidak.

$\mathrm{H}_{0}$ : Populasi kedua sampel sama atau homogen.

$\mathrm{H}_{a}$ : Populasi kedua sampel tidak sama atau tidak homogen.

Uji homogenitas dilakukan dengan menggunakan bantuan program SPSS 22 Levene's Testpada taraf signifikansi $\alpha 5 \%$. Kriteria untuk melakukan uji homogenitas pada tingkat signifikansi $\alpha 5 \%$ adalah populasi kedua sampel dinyatakan sama atau homogen atau $\mathrm{H}_{0}$ diterima jika nilai signifikansi lebih besar dari nilai $\alpha$ $($ sig. $>\alpha)$

Setelah kedua uji asumsi di atas terpenuhi, maka untuk mengetahui keefektifan pembelajaran berbasis potensi lokal pembuatan gerabah dan mebel Jepara dalam meningkatkan keterampilan berpikir kritis peserta didik dilakukan uji t. Aapun hipotesis uji t adalah sebagai berikut.

$\mathrm{H}_{0}$ : Perangkat pembelajaran IPA berbasis potensi lokal Jepara tidak lebih efektif dibandingkan dengan perangkat pembelajaran yang biasa digunakan dalam meningkatkan keterampilan berpikir kritispeserta didik SMP

$\mathrm{H}_{\mathrm{a}}$ : Perangkat pembelajaran IPA berbasis potensi lokal Jepara lebih efektif dibandingkan dengan perangkat pembelajaran yang biasa digunakan dalam meningkatkan keterampilan berpikir kritis peserta didik SMP

Uji t dilakukan pada taraf signifikansi $\alpha$ $5 \%$ dengan bantuan program SPSS 22. Kriteria penerimaan atau penolakan $\mathrm{H}_{0}$ pada taraf siginfikansi $\alpha 5 \%$ adalah:

a. $\mathrm{H}_{0}$ ditolak jika sig. $<\alpha$.

b. $\mathrm{H}_{0}$ diterima jika sig. $>\alpha$. 


\section{HASIL DAN PEMBAHASAN}

Selama pembelajaran berlangsung, terdapat dua observer yang mengamati keterlaksanaan RPP dalam pembelajaran. Data hasil pengamatan observer dianalisis seperti disajikan dalam Tabel 1.

Berdasarkan Tabel 1, pada tiap pertemuan pembelajaran yang menggunakan RPP berbasis potensi lokal pembuatan gerabah dan mebel Jepara hasil pengembangan menghasilkan kesimpulan percentage of agreement lebih besar dari $75 \%$, sehingga termasuk dalam kriteria baik. Masing-masing percentage of agreementtiap pertemuan sebesar dirata-rata. Rata-rata percentage of agreement dari pertemuan pertama hingga ketiga adalah 96,83\%. Sesuai ketentuan, jika percentage of agreement lebih besaar dari $75 \%$, maka kriteria keterlaksanaan RPP tersebut adalah baik. Peserta didik juga terlihat sangat antusias dalam mengikuti pembelajaran, baik pembelajaran di dalam kelas, di dalam laboratorium, maupun pembelajaran di luar kelas yaitu pada saat kunjungan ke tempat pembuatan gerabah di Kecamatan Mayong dan pembuatan mebel di Kecamatan Mlonggo.

Berdasarkan data skor pretest dan skor posttest keterampilan berpikir kritis yang diperoleh, dapat ditentukan skor gain standar dari keterampilan berpikir kritisnya.Skor pretest, posttest dan gain standar keterampilan berpikir kritis yang telah diperoleh, dirangkum hingga beberapa depkripsi data yang dibutuhkan dapat disajikan. Deskripsi data skor hasil pretest dan posttest serta gain standar keterampilan berpikir kritis peserta didik pada kelas eksperimen dan kelas kontrol disajikan dalam Tabel 2.

Berdasarkan Tabel 2, analisis terhadap rata-rata skor gain standar $(<\mathrm{g}\rangle)$ yang dilakukan memperoleh nilai rata-rata gain standar keterampilan berpikir kritis pada kelas eksperimen sebesar 0,58 dan pada kelas kontrol sebesar 0,25. Rata-rata gain standar pada kelas eksperimen berada pada kategori sedang dan rata-rata pada kelas kontrol berada pada kategori rendah. Berdasarkan analisis tersebut dapat diketahui peningkatan skor keterampilan berpikir kritis peserta didik kelas eksperimen jauh lebih tinggi dari pada peserta didik kelas kontrol. Peningkatan ini dimungkinkan oleh pengalaman langsung dari interaksi peserta didik dengan para pengrajin gerabah maupun mebel. Peserta didik juga menjadi lebih kreatif dan leluasa dalam menggali dan menganalisis segala informasi terkait materi pembelajaran secara mendalam terhadap sumber belajar terkait, sehingga pembelajaran menjadi lebih bermakna yang menjadikan keterampilan berpikir kritis yang sudah dimiliki peserta didik menjadi lebih tergali dan meningkat.

Data pretest dan posttest keterampilan berpikir kritis antara kelas eksperimen dan kelas kontrol juga menunjukkan adanya perbedaan peningkatan. Grafik perbandingan rata-rata nilai pretest dan posttest pada data keterampilan berpikir kritis antara kelas eksperimen dan kelas kontrol disajikan pada Gambar 5.

Tabel 1. Rekapitulasi Analisis Hasil Observasi Keterlaksanaan RPP

\begin{tabular}{cccccccc}
\hline No. & $\begin{array}{c}\text { Pertemuan } \\
\text { ke- }\end{array}$ & Observer & $\begin{array}{c}\text { Jumlah Butir } \\
\text { Terlaksana }\end{array}$ & $\begin{array}{c}\text { \% } \\
\text { Keterlaksanaan }\end{array}$ & $\begin{array}{c}\text { \% of } \\
\text { Agreement }\end{array}$ & Rata-Rata & Kriteria \\
\hline 1. & 1 & 1 & 15 & 83,33 & 96,55 & & \\
& & 2 & 14 & 77,78 & & & \\
2. & 2 & 1 & 16 & 88,89 & 96,97 & $96,83 \%$ & Baik \\
3. & 2 & 1 & 17 & 94,44 & & & \\
\hline
\end{tabular}

Tabel 2. Rekapitulasi Hasil Pengukuran Keterampilan Berpikir Kritis

\begin{tabular}{clcccccc}
\hline \multirow{2}{*}{ No. } & \multirow{2}{*}{ Komponen } & \multicolumn{3}{c}{ Kelas Eksperimen } & \multicolumn{3}{c}{ Kelas Kontrol } \\
\cline { 3 - 8 } & & Pretest & Postest & $\langle\mathbf{g}\rangle$ & Pretest & Postest & $\langle\mathbf{g}\rangle$ \\
\hline 1. & Jumlah Subjek & 40 & 40 & 40 & 39 & 39 & 39 \\
2. & Nilai Tertinggi & 66 & 94 & 0,84 & 70 & 85 & 0,50 \\
3. & Nilai Terendah & 39 & 67 & 0,40 & 37 & 43 & 0,05 \\
4. & Rata-rata & 50,18 & 79,15 & 0,58 & 49,26 & 61,36 & 0,25 \\
\hline
\end{tabular}

Keterangan: $\langle\mathrm{g}\rangle$ : gain standar 
Jurnal Inovasi Pendidikan IPA, 3 (1), 2017 - 8

Aries Anisa

Tabel 3. Hasil Uji Normalitas Saphiro-Wilk

\begin{tabular}{lccccc}
\hline \multirow{2}{*}{ No. } & \multirow{2}{*}{ Variabel } & \multicolumn{2}{c}{ Kelas Eksperimen } & \multicolumn{2}{c}{ Kelas Kontrol } \\
\cline { 3 - 6 } & & Sig. & Kesimpulan & Sig & Kesimpulan \\
\hline 1. & Keterampilan Berpikir Kritis & 0,061 & $\mathrm{H}_{0}$ diterima & 0,121 & $\mathrm{H}_{0}$ diterima \\
\hline
\end{tabular}

Tabel 4. Rangkuman Hasil Uji Homogenitas (Levene's test)

\begin{tabular}{cccc}
\hline No. & Variabel & Sig & Kesimpulan \\
\hline 1. & Keterampilan Berpikir Kritis & 0,417 & $\mathrm{H}_{0}$ diterima \\
\hline
\end{tabular}

Tabel 5. Rangkuman Hasil Uji t

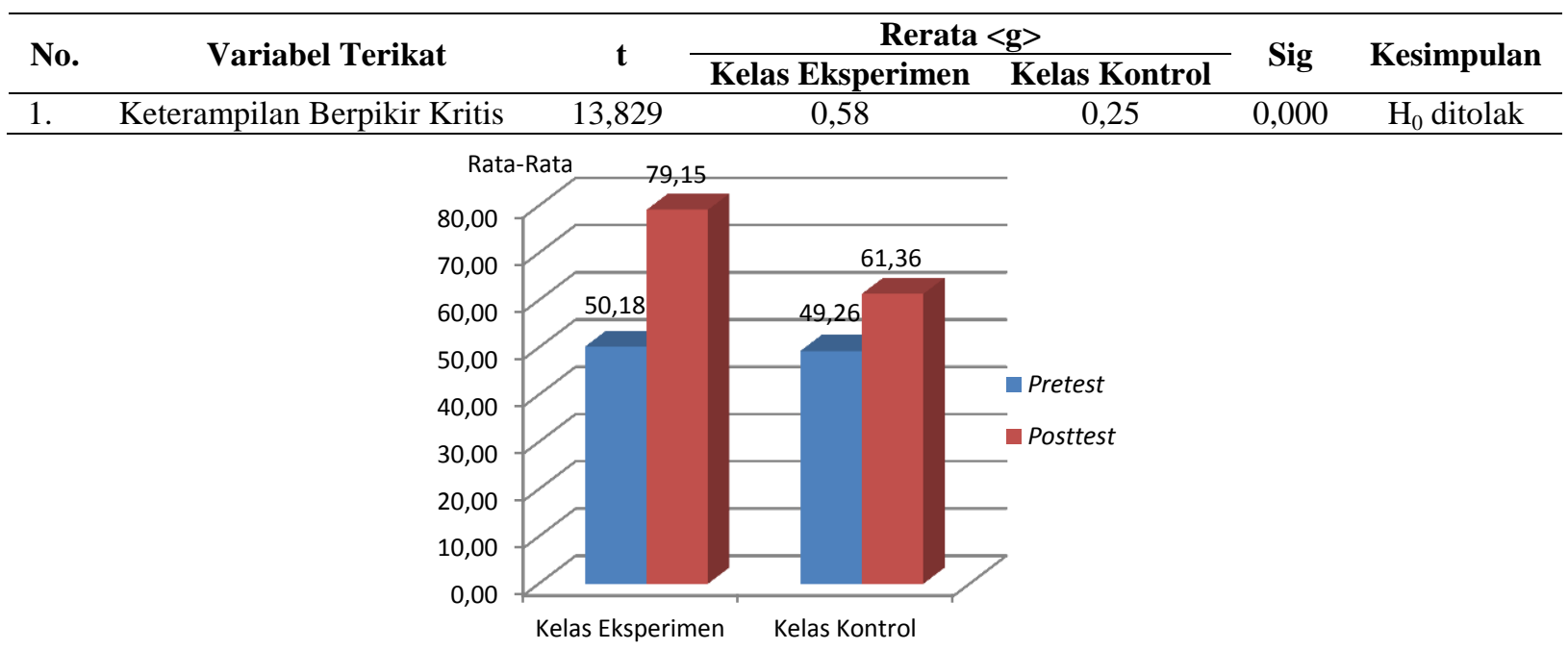

Gambar 5. Perbandingan Rata-Rata Pretest dan Posttest Keterampilan Berpikir Kritis antara Kelas Eksperimen dan Kelas Kontrol

Berdasarkan nilai rata-rata, skor gain standar pada kelas eksperimen lebih tinggi dari pada kelas kontrol. Berdasarkan kategori gain standar yang dikemukakan oleh Hake (1999), skor rata-rata gain standar keterampilan berpikir kritis pada kelas eksperimen berada pada kategori sedang dan pada kelas kontrol berada pada kategori rendah, dapat diketahui peningkatan skor gain standar keterampilan berpikir kritis peserta didik kelas eksperimen jauh lebih tinggi dari pada peserta didik kelas kontrol.

Adapun grafik perbandingan perolehan rata-rata skor gain standar antara kelas eksperimen dan kelas kontrol disajikan dalam Gambar 6.

Untuk mengetahui efektivitas pembelajaran, dilakukan uji t terhadap data yang ada. Sebelum uji t dilakukan, diperlukan uji asumsi univariat terlebih dahulu. Adapun uji asumsi univariat yang dilakukan adalah uji normalitas dan uji homogenitas.

Uji normalitas univariat Saphiro-Wilk dilakukan pada data skor gain standar masingmasing kelas eksperimen maupun kontrol dengan program SPSS 22. Berdasarkan analisis uji normalitas data didapatkan bahwa data berasal dari populasi yang berdistribusi normal atau $\mathrm{H}_{0}$ diterima dengan sig. $>\alpha$ pada taraf signifikansi 5\%. Hasil uji normalitas disajikan dalam Tabel 3.

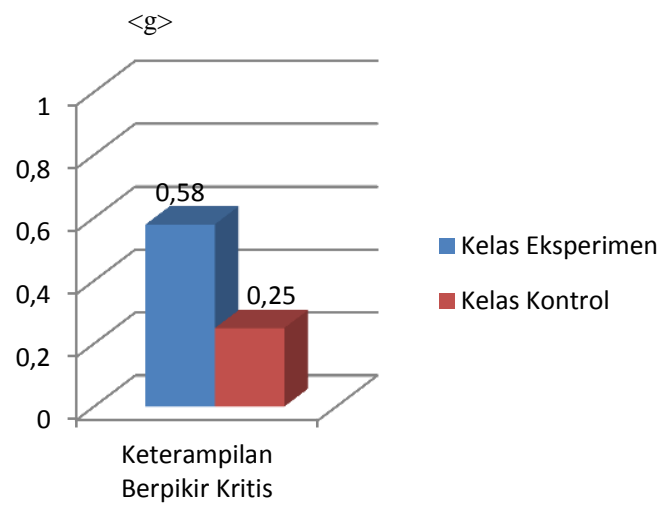

Gambar 6. Grafik Perbandingan Skor Gain Standar Keterampilan Berpikir Kritis Peserta Didik Kelas Eksperimen dan Kelas Kontrol pada Uji Coba Lapangan

Uji homogenitas dilakukan menggunakan Levene's Test program SPSS 22. Uji homogenitas dari data dapat disimpulkan bahwa data 
sampel berasal dari populasi yang homogen jika $\mathrm{H}_{0}$ diterima dengan sig. $>\alpha$ pada taraf signifikansi 5\%. Hasil uji homogenitas menunjukkan data sampel berasal dari populasi yang homogen. Hasil uji homogenitas univariat disajikan dalam Tabel 4.

Uji normalitas univariat dari masingmasing variabel terikat dan kelas perlakuan didapatkan bahwa data berasal dari populasi yang berdistribusi normal berdasarkan nilai sig. 0,061 dan 0,121. Kedua kelas perlakuan memperoleh nilai sig. masing-masing di atas nilai $\alpha$ 5\%. Uji homogenitas Levene's test yang telah dilakukan mendapatkan nilai sig. 0,417 yang lebih besar dari $\alpha 5 \%$. Berdasarkan hasil ini dapat disimpulkan bahwa sampel berasal dari populasi yang homogen.

Kedua uji asumsi yang telah dilakukan, dapat dilakukan telah terpenuhi sebagai prasyarat uji t. Selanjutnya uji t pada variabel keterampilan berpikir kritis dapat dilakukan.Uji $\mathrm{t}$ ini dilakukan untuk mengetahui perbedaan efektivitas penggunaan perangkat IPA berbasis potensi lokal Jepara sebagai hasil pengembangan untuk meningkatkan keterampilan berpikir kritis peserta didik.

Efektivitas penggunaan perangkat IPA berbasis potensi lokal Jepara sebagai hasil pengembangan dibandingkan perangkat pembelajaran IPA yang biasa digunakan guru dalpad dilihat dari perbedaan rerata skor gain pada masing-masing kelas perlakuan dalam meningkatkan keterampilan berpikir kritis. Hasil uji t pada data skor gain standar keterampilan berpikir kritis disajikan dalam Tabel 5.

Berdasarkan hasil uji t pada Tabel 5, dapat disimpulkan bahwa pembelajaran IPA berbasis potensi lokal Jepara efektif. Keefektifan pembelajaran IPA yang menggunakan perangkat pembelajaran berbasis potensi lokal Jepara dalam meningkatkan keterampilan berpikir kritis peserta didik SMP ini dibandingkan dengan pembelajaran yang dilakukan oleh guru dengan perangkatyang pembelajaran yang biasa digunakan. Hal ini dimungkinkan karena penggunaan LKPD oleh peserta didik serta kunjungan ke potensi lokal pembuatan gerabah di kecamatan Mayong dan mebel Jepara di Kecamatan Mlonggo sebagai bagian proses pembelajaran IPA membuat peserta didik memperoleh pengalaman langsung dalam belajar.

Kegiatan kunjungan ke tempat potensi lokal pembuatan gerabah di Kecamatan Mayong dan mebel Jepara di Kecamatan Mlonggo merupakan salah satu cara melibatkan potensi lokal yang ada dalam pembelajaran IPA terkait. Pelibatan potensi lokal seperti ini memberikan pengalaman berbeda bagi peserta didik dan menjadikan pembelajaran lebih kontekstual dan bermakna serta memberikan pemahaman yang mendalam. Peserta didik lebih aktif dan kreatif dalam memperoleh informasi secara langsung dari para pengrajin. Hal ini sejalan dengan pendapat Parker \& Chao (2007) yang mengungkapkan bahwa belajar menjadi lebih bermakna jika dilakukan pada komunitas nyata dalam praktik kehidupan sehari-hari. Pembelajaran ini juga memberikan contoh langsung tentang kreatifitas dan strategi memecahkan masalah dalam usaha maupun kehidupan sehari-hari yang nyata, sehingga mampu meningkatkan keterampilan berpikir kritis peserta didik sebagai generasi penerus bangsa dalam era MEA di abad XXI.

\section{SIMPULAN DAN SARAN}

Berdasarkan hasil analisis data yang telah dilakukan, dapat disimpulkan bahwa pembelajaran IPA berbasis potensi lokal Jepara efektif untuk meningkatkan keterampilan berpikir kritis peserta didik SMPN 1 Bangsri Kabupaten Jepara. Keefektifan ini dimungkinkan karena pembelajaran berbasis potensi lokal pembuatan gerabah dan mebel Jepara memberikan pengalaman langsung bagi peserta didik dalam menggali informasi secara kreatif dan memberikan pemahaman yang mendalam, sehingga menjadikan pembelajaran lebih bermakna serta mampu meningkatkan keterampilan berpikir kritis peserta didik.

Berdasarkan hasil penelitian yang telah dilakukan, saran yang dapat diberikan adalah sebagai berikut. Pertama, guru IPA SMP di wilayah Kabupaten Jepara hendaknya dapat memanfaatkan potensi lokal Jepara pembelajaran IPA di sekolah, agar peserta didik dapat belajar secara kontekstual dan bermakna tentang materi IPA langsung dengan sumber belajar yang tepat.

Kedua, pembelajaran IPA berbasis potensi lokal Jepara, terutama pelibatan potensis lokal pembuatan gerabah dan mebel Jeparadiharapkan dapat menjadi contoh bagi guru dalam membuat pembelajaran yang melibatkan potensi lokal yang terdapat disekitar sekolah.

Ketiga, untuk daerah yang berbeda karakteristik potensi lokalnya, guru dapat memodifikasi potensi lokal yang diintegrasikan dalam proses pembelajaran sesuai kondisi. 


\section{Jurnal Inovasi Pendidikan IPA, 3 (1), 2017 - 10}

Aries Anisa

\section{DAFTAR PUSTAKA}

Afrizon, R., Ratnawulan, \& Fauzi, A. (2012). Peningkatan perilaku berkarakter dan keterampilan berpikir kritis siswa kelas IX MTsN model padang pada mata pelajaran IPA-Fisika menggunakan model problem based instruction. Jurnal Penelitian Pembelajaran Fisika .

Borich, G. D. (1994). Observation skills for effective teaching. New York: Macmillan Publishing Company.

Cavus, N., \& Uzunboylu, H. (2009). Improving critical thinking skills in mobile learning. Procedia Social and Behavioural Sciences, 1 (2009), 434-438.

Collete, A. T., \& Chiappetta, E. L. (1994). Science instruction in the middle and secondary schools. New York: Macmillan Publishing Company.

Ennis, R. H. (1985). A logical basis for measuring critical thinking skills. Association for Supervisi and Curriculum Development.

Fahim, M. (2012). Manipulating critical thinking skills in test taking. International Journal of Education, 4 (1), 153-160.

Hake, R. R. (1999). Analyzing change/gain score. Woodland Hills: Indiana University.

Hunter, D. A. (2009). A practical guide to critical thinking: Deciding what to do and believe. New Jersey: John Wiley \& Sons, Ltd.

Kanzunnudin, M., \& Oktavianti, I. (2014). Mengikis diskriminasi anak di sekolah melalui pengembangan keterampilan sosial siswa pada pembelejaran IPS berbasis keunggulan lokal kudus melalui penerapan recriprocal learning berbantu media dan metrik ingatan. Seminar Nasional (pp. 70-79). Kudus: Universitas Muria Kudus.

Khusniati, M. (2014). Model pembelajaran sains berbasis kearifan lokal dalam menumbuhkan karakter konservasi. Indonesian Journal of Conservation, 3 (1), 67-74.

Meltzer, D. E. (2002). The relationship between mathematics preparation and conceptual learning gains in physics: A possible"hidden variable" in diagnostic pretest scores. Journal of Research. Indiana: Vol 47 No 12.

Mendikbud. (2014). Ilmu pengetahuan alam SMP/Mts kelas VIII semester 1. Jakarta: Puskurbuk, Balitbang, Kemendikbud.

Mendikbud. (2014). Peraturan Menteri Pendidikan dan Kebudayaan Nomor 103 Tahun 2014, tentang pembelajaran pada pendidikan dasar dan pendidikan menengah.

Mumpuni, K. E. Potensi pendidikan keunggulan lokal berbasis karakter dalam pembelajaran biologi di Indonesia. Seminar Nasional X Pendidikan Biologi FKIP UNS. Solo: Seminar Nasional $\mathrm{X}$ Pendidikan Biologi FKIP UNS.

Parmin, Sajidan, Ashadi, \& Sutikno. (2015). Skill of prospective teacher in integrating the concept of science with local wisdom model. Indonesian Journal odf Science Education, 120-126.

RepublikIndonesia. (2003). Undang-Undang RI No. 20 Tahun 2003.

Santoso, M. A. (2010). Konsep diri melalui pendidikan berbasis keunggulan lokal sebagai model pendidikan berkarakter dan berbudaya bangsa di era global. The 4th International Conference on Teacher Education: Join Conference UPI \& UPSI (pp. 477-486). Bandung: UPI \& UPSI.

Sendag, S., \& Odabasi, H. F. (2009). Effects of online problem based learning course on content knowledge acquisition and critical thinking skills. Computers \& Education, 53 (2009), 132-141.

Sugiyono. (2014). Metode penelitian pendidikan (pendekatan kuntitatif, kualitatif, dan $R \&$ $D)$. Bandung: Alfabeta.

Sunarto, Marfai, M. A., \& Setiawan, M. A. (2014). Geomorfologi dan dinamika pesisir Jepara. Yogyakarta: Gajah Mada University Press .

Syarifah, \& Sumardi, Y. (2015). Pengembangan model pembelajaran malcolm's modelling untuk meningkatkan keterampilan berpikir kritis dan motivasi belajar siswa. Jurnal Inovasi Pendidikan IPA, 1 (2), 237-247.

Uswatun, D. A., \& Rohaeti, E. (2015). Perangkat pembelajaran IPA berbasis inkuiri untuk meningkatkan critical thinking skills dan scintific attitude siswa. 
Jurnal Inovasi Pendidikan IPA, 3 (1), 2017 - 11

Aries Anisa

Jurnal Inovasi Pendidikan IPA, 1 (2), Williams, J. D. (2011). How science work 138-152.

Wahyuni, S. Mengembangkan keterampilan berpikir kritis siswa melalui pembelajaran IPA berbasis problembased learning. FMIPA FKIP-UT. (teaching and learning in the science classroom). New York: Continuum International Publishing Group. 